of treatment and also later, when the patient is apparently adequately treated according to the prothrombin ratio. It appears that patients with venous lesions require more anticoagulant to produce the same partial thromboplastin clottingtime than do patients with arterial lesions, and this may have a bearing on relapses and further thromboses. Examination of results from 21 patients when they were bleeding suggests that the partial thromboplastin clotting-time may be a better test for the detection of potential bleeding and bruising after overtreatment, since it is sensitive to variations in concentration of factor IX, a factor which does not affect the prothrombin clottingtime. It is therefore proposed that the plasma partial thromboplastin clotting-time is the more valuable test for the control of oral anticoagulant treatment, and a suggested therapeutic range of values is given.
I am grateful to my clinical colleagues for access to clinical case notes, to Dr. J. M. Naish for advice and encouragement, and to the technical staff of the haematology section for their enthusiastic assistance in this work.

\section{REFERENCES}

Biggs, R., and Denson, K. W. E. (1967). Brit. med. F., 1, 84 Denson, K. W. (1961). Brit. med. ₹., 1, 1205.

Eastham, R. D. (1962). \%. clin. Path., 15, 86.

Eastham, R. D., and Morgan, E. H. (1964). Lancet, 2, 543.

Goulian, M., and Beck, W. S. (1965). Amer. F. clin. Path., 44, 97

Nye, S. W., Graham, J. B., and Brinkhous, K. M. (1962). Amer. F. med. Sci., 243, 279.

Poller, L. (1964). Brit. med. 7., 2, 565.

Quick, A. J. (1942). The Hemorrhagic Diseases and the Physiology of Hemostasis. Springfield, Illinois.

Spector, I., and Corn, M. (1967). F. Amer. med. Ass., 201, 157

Wessler, S. (1962). Amer. F. Med., 33, 648.

\title{
Clinical Trial of Disodium Cromoglycate in Treatment of Asthma in Children
}

\author{
J. MORRISON SMITH,* M.D., F.R.C.P.ED., D.P.H., D.T.M.\&H., T.D.D.; G. F. DEVEY,* M.B., CH.B., D.P.H.
}

Brit. med. F., 1968, 2, 340-344

Disodium cromoglycate (FPL 670 ; Intal) is one of a series of chromone derivatives studied by Fisons Pharmaceuticals Limited. It has been shown to inhibit the effects of some specific types of reaginic antibody-antigen reactions. It is not an anti-inflammatory agent and it is not a bronchodilator, nor does it protect against the effect of histamine, of 5-hydroxytryptamine, or of slow-reacting substance (SRS-A).

The compound has been shown to be relatively non-toxic. In acute toxicity tests in small laboratory animals the $\mathrm{LD}_{50}$ on parenteral administration was greater than $2,000 \mathrm{mg} . / \mathrm{kg}$. In prolonged tests no toxic effects were seen, except at doses greater than $30 \mathrm{mg}$. $/ \mathrm{kg}$. Renal tubular degeneration was the only specific toxic effect noted at higher dosage. The compound is excreted rapidly in the bile and urine and there is no evidence in animals of accumulation in any tissue (Cox, 1967).

Experimentally in atopic volunteers there was a reduction of the bronchospasm induced by aerosol of the appropriate antigen when the compound was administered by inhalation previous to challenge. Only a small fraction (less than 10\%) of the inhaled dose in man is absorbed, and it is rapidly excreted. When given by mouth less than $1 \%$ is absorbed, and its protective effect is probably insufficient to be of clinical value (Altounyan, 1968).

A small double-blind crossover trial in adults showed significant clinical improvement in patients with allergic pulmonary disease (Howell and Altounyan, 1967). On the basis of this and further clinical experience which has since been reported (Altounyan and Howell, 1968) these authors concluded that disodium cromoglycate is a major advance in the management of allergic airway disease. This view was supported by Kennedy (1967) but was not shared by Grant et al. (1967). The present study was designed to evaluate the efficacy of this drug in the treatment of children suffering from asthma.

\section{Method of Administration}

A plastic inhaler (Spinhaler) has been designed for the inhalation of the drug, which is dispensed as a micronized powder

\footnotetext{
- From the Asthma Clinic, Birmingham School Health Service.
}

in gelatin capsules. The patient inhales the powder by taking a few deep breaths through the Spinhaler; in practice this appliance has proved easy to use by co-operative children even with fairly severe asthma. It is easily cleaned and maintained, and incorporates a simple means of puncturing the capsules.

\section{Plan of Trial}

The object of the trial was to compare on a double-blind basis, using crossover technique, the condition of children with asthma, present throughout the year, during two periods of four weeks each.

The children inhaled the contents of four capsules a day (on rising, at lunch-time, at tea-time, and on retiring) during the whole trial. In one four-week period the capsules contained disodium cromoglycate, in the other a placebo. The order of treatment for each patient was allocated at random and was not known to anyone concerned in the trial until the final assessments were completed. During a two-week period before the trial the children had experience in the use of the Spinhaler when they were supplied with practice capsules; initial biochemical and other observations were also made at this time.

The trial capsules were coloured pink, the practice capsules were colourless. The "active" capsules contained disodium cromoglycate $20 \mathrm{mg}$., isoprenaline sulphate $0.1 \mathrm{mg}$., and lactose $19.9 \mathrm{mg}$. The placebo capsules contained isoprenaline sulphate $0.1 \mathrm{mg}$., lactose $34.9 \mathrm{mg}$., and sodium sulphate (anhydrous) $5 \mathrm{mg}$. The practice capsules contained isoprenaline sulphate $0.1 \mathrm{mg}$. and lactose $39.9 \mathrm{mg}$.

The small dose of isoprenaline sulphate was included in the capsules to prevent bronchospasm, which may occur after the inhalation of a dry powder. Sodium sulphate was included in the placebo capsules to impart a slightly unpleasant taste similar to the "active" capsules. No other change was made in the routine treatment except when the clinical condition required an alteration in the dosage of antispasmodics or corticosteroids (see below).

Before inclusion of the children in the trial the nature of the project was carefully explained to them and their parents both 
verbally and in writing; the family doctors were also informed by letter.

\section{Patients Included in Trial}

A total of 51 patients were admitted to the trial. Of these 41 were boys and 10 were girls. The average age was 10.8 years; the youngest was 5 and the eldest 16. They were all children with long-standing perennial asthma and most had been attending the clinic for a number of years. Seventeen of the 51 also had active flexural eczema.

No attempt was made to exclude children on long-term steroid treatment; indeed, as many as possible were included so as to embrace the more severe and persistent cases of asthma.

Twenty-two were on long-term steroid treatment before the trial started and the average duration of such treatment was two and a half years. The dose used varied from 15 to $2.5 \mathrm{mg}$. of prednisolone (or its equivalent) daily.

\section{Methods of Assessment}

Daily Records. - Each patient, with the help of a parent, was instructed how to keep a day and night record of asthma, cough, sputum, and all medicines taken; these were entered on to a printed card, the numerical scoring for symptoms shown on the back of the card (Fig. 1) being used. Most of the patients had been used to keeping a similar but simpler record during their attendance at the clinic. One of us checked the cards at each weekly attendance.

Questionary.-At the end of each four-week period a questionary was completed by one of us recording the patient's answers to the following questions: (a) On the whole in the preceding four weeks have your chest symptoms been: about the same, definitely or slightly worse, very much worse, definitely or slightly better, or very much better ? (b) If you have noted a change in the past four weeks which symptoms have changed: wheeze, chest tightness, breathlessness on exertion, sputum, cough, or sleep ? In each case was the symptom better or worse? (c) Have you had any unpleasant or unusual symptoms?

Patient's Preference.-On completion of the trial each patient was asked whether he or she would prefer to stop using the Spinhaler, to continue to use it with the capsules supplied in the first four-week period, or use it with those in the second four-week period.

Spirometry.-Each week throughout the trial the F.E.V. and F.V.C. were recorded both before and after inhalation of a $1 \%$ solution of isoprenaline sulphate for half a minute from a Bright-Smith nebulizer.

Requirements for Other Drugs.-(1) Bronchodilators. The use of bronchodilator aerosols was varied by the patient according to symptoms. The number of doses required during each

\begin{tabular}{|c|c|c|c|c|c|c|c|}
\hline \multicolumn{4}{|c|}{ ASTHMA SCORE } & \multicolumn{2}{|c|}{ COUGH SCORE } & \multicolumn{2}{|c|}{ SPUTUM SCORB } \\
\hline Score & Grade & During the Day & During the Night & Score & Grade & Score & Sputum Volume \\
\hline 1 & Terrible & $\begin{array}{l}\text { Unable to move about. In bed or } \\
\text { chair most of the day-very } \\
\text { breathless. }\end{array}$ & $\begin{array}{l}\text { Kept awake most of the night by } \\
\text { asthma }\end{array}$ & 1 & $\begin{array}{l}\text { Distressing cough } \\
\text { most of the time. }\end{array}$ & 1 & $\begin{array}{l}\text { A lot (egg cup or } \\
\text { more). }\end{array}$ \\
\hline 2 & Very bad & $\begin{array}{l}\text { Able to walk slowly about the house } \\
\text { but becoming very breathless. }\end{array}$ & $\begin{array}{l}\text { Woken by asthma almost hourly but } \\
\text { able to sleep in between attacks. }\end{array}$ & 2 & $\begin{array}{l}\text { Distressing cough } \\
\text { in attacks only. }\end{array}$ & 2 & Occasional blobs. \\
\hline 3 & Moderately bad & $\begin{array}{l}\text { Able to climb stairs slowly or walk } \\
\text { slowly out of doors but cannot } \\
\text { keep up a normal pace. }\end{array}$ & $\begin{array}{l}\text { Woken by asthma 4-6 times but } \\
\text { sleeping in between. }\end{array}$ & 3 & $\begin{array}{l}\text { Occasional cough, } \\
\text { not distressing }\end{array}$ & 3 & None. \\
\hline 4 & Slightly bad & $\begin{array}{l}\text { Able to walk outside at normal pace } \\
\text { but cannot hurry without getting } \\
\text { very breathless. }\end{array}$ & $\begin{array}{l}\text { Woken by asthma } 2-3 \text { times. Other- } \\
\text { wise sleeping well. }\end{array}$ & 4 & No cough. & & \\
\hline 5 & Moderately well & $\begin{array}{l}\text { Able to hurry but unable to run } \\
\text { short distances without becom- } \\
\text { ing very breathless. }\end{array}$ & $\begin{array}{l}\text { Woken once by asthma, otherwise } \\
\text { slept well. }\end{array}$ & & & & \\
\hline 6 & Very well & $\begin{array}{l}\text { Able to run and play games without } \\
\text { feeling uncomfortable. }\end{array}$ & Slept through the night. & & & & \\
\hline
\end{tabular}

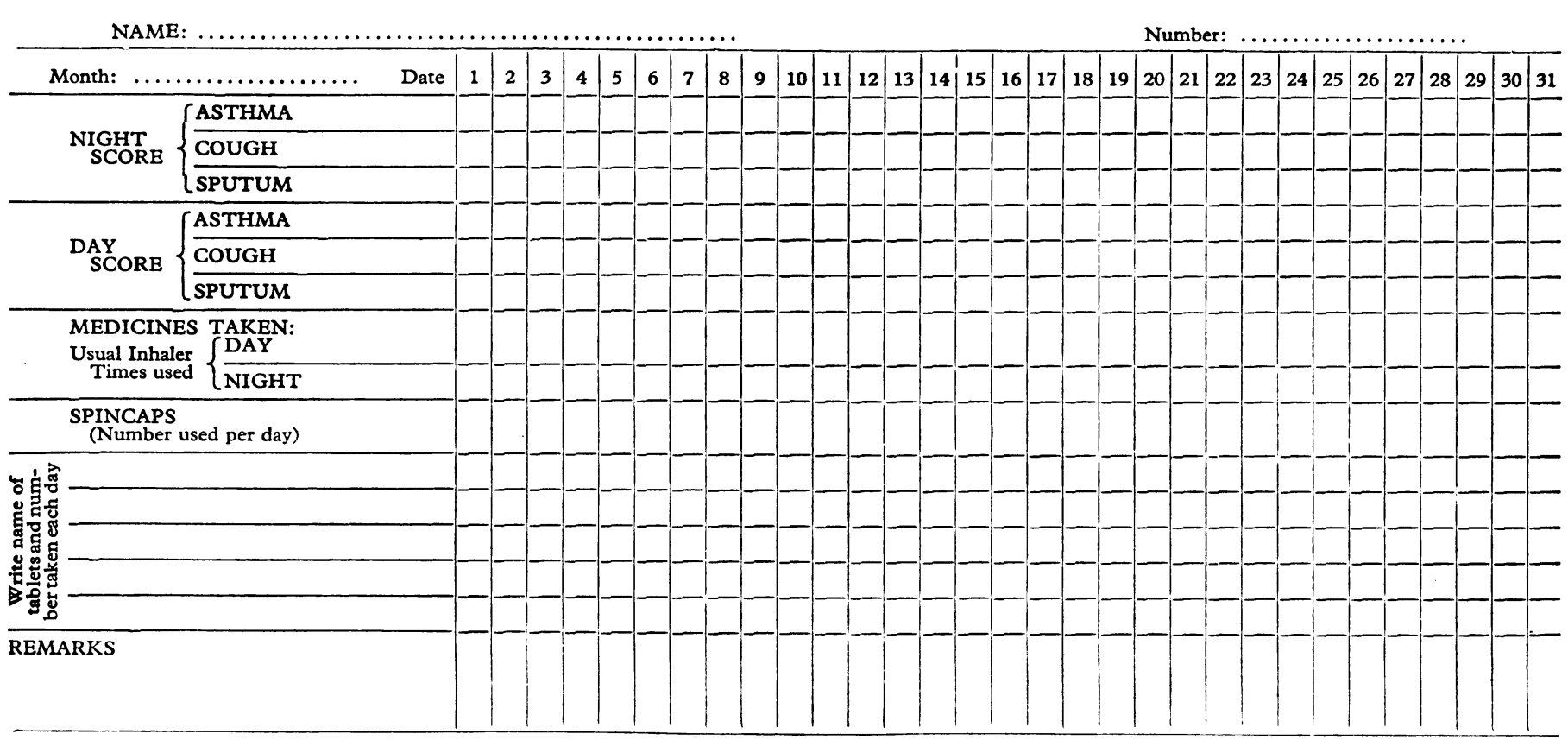

FIG. 1.-Score card. 
day and night was entered separately on the daily record card. (2) Corticosteroids. Dosage requirements were adjusted by the physician who was not supervising weekly recordings or completing the questionaries. He came to his decision on the basis of his own clinical assessment of the patient's condition ; where improvement allowed the dose was decreased, and where the patient was thought to be in more distress or danger the dose was increased. Such adjustments have been the normal practice in this clinic for patients on long-term steroid therapy

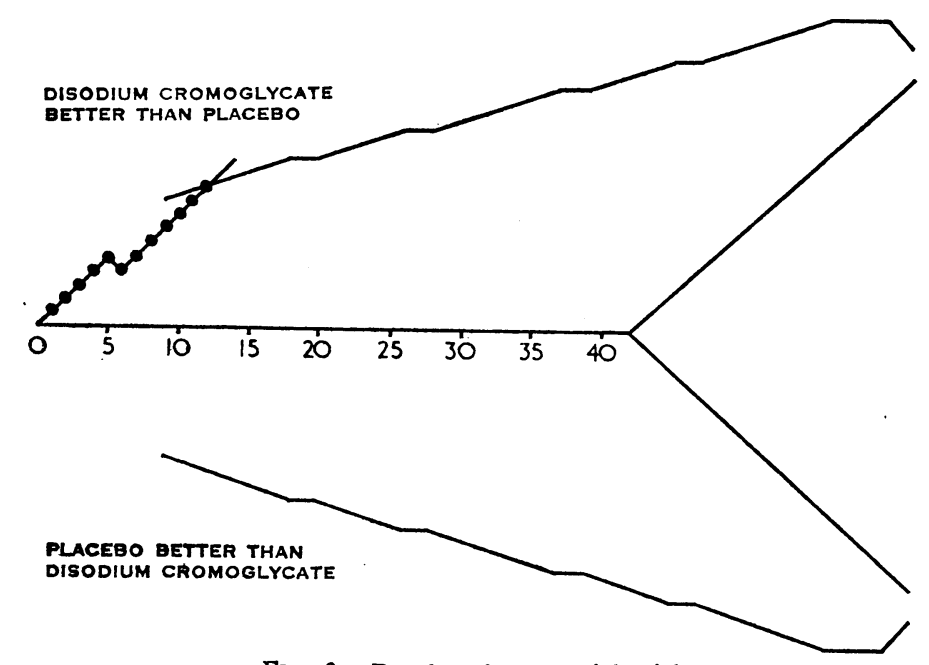

Fig. 2.-Results of sequential trial.
(Smith, 1965), and it was not regarded as ethical to alter it for the purpose, of this trial.

Independent Assessor.-When the records for each patient were completed they were submitted in the form of tables and graphs to an experienced chest physician who was not associated with the work of the clinic and who was also unaware of the treatment code during the two periods of four weeks. He was asked to make an assessment, on all the evidence presented, whether the patient had been significantly better during one or other period or whether there was no difference. The results of his assessment were sent to another colleague, who held the key to the treatment code, so that he was able to enter them on to a sequential diagram.

\section{Results}

\section{Sequential Analysis}

A diagram was prepared to allow for improvement in $50 \%$ of cases independent of specific treatment. If a further $25 \%$ or more cases showed improvement during the "active" period this was regarded as a statistically significant result in favour of the drug. In recording the results for each patient the two periods of four weeks were taken to constitute a pair. The results obtained are shown in Fig. 2. Altogether 18 cases were required to reach a statistically significant result in favour of the drug. Eleven of these cases were thought by the assessor to have improved during the "active" period, whereas only one improved during the "placebo" period. Five cases were considered to have shown no significant change during either

TABLE I.-Results of Double-blind Crossover Trial of Disodium Cromoglycate

\begin{tabular}{|c|c|c|c|c|c|c|c|c|c|c|c|c|c|c|c|c|c|}
\hline \multirow{3}{*}{$\begin{array}{l}\text { Case } \\
\text { No. }\end{array}$} & \multirow{3}{*}{ Age } & \multicolumn{2}{|c|}{ Preference } & \multirow{2}{*}{\multicolumn{2}{|c|}{$\begin{array}{c}\text { Asthma } \\
\text { Disability Score } \ddagger\end{array}$}} & \multirow{2}{*}{\multicolumn{2}{|c|}{$\begin{array}{l}\text { F.E.V.1 as \% } \\
\text { of Predicted\$ }\end{array}$}} & \multirow{2}{*}{\multicolumn{2}{|c|}{$\begin{array}{l}\text { F.V.C. as \% } \\
\text { of Predicted\$ }\end{array}$}} & \multirow{2}{*}{\multicolumn{2}{|c|}{$\begin{array}{c}\% \text { Change\| } \\
\text { During Active } \\
\text { as Compared } \\
\text { With Placebo }\end{array}$}} & \multicolumn{4}{|c|}{$\begin{array}{l}\text { Average Daily Dose } \\
\text { in mg. of Steroids }\end{array}$} & \multirow{2}{*}{\multicolumn{2}{|c|}{$\begin{array}{l}\text { Inhaler } \\
\text { Usage }\end{array}$}} \\
\hline & & \multirow{2}{*}{$\begin{array}{l}\text { Asses- } \\
\text { sor's" }\end{array}$} & \multirow{2}{*}{ Patient's $t$} & & & & & & & & & & & & 3 mths. & & \\
\hline & & & & Active & Placebo & Active & Placebo & Active & Placebo & F.E.V.1 & F.V.C. & & F saceov & active & $\begin{array}{l}\text { Trial on } \\
\text { Active }\end{array}$ & Active & Placebo \\
\hline $\begin{array}{r}1 \\
2 \\
3 \\
4 \\
5 \\
6 \\
8 \\
9 \\
10 \\
11 \\
12 \\
13 \\
14 \\
15 \\
16 \\
17 \\
18 \\
19 \\
20 \\
21 \\
22 \\
23 \\
24 \\
25 \\
26 \\
28 \\
29 \\
30 \\
33 \\
34 \\
35 \\
36 \\
37 \\
38 \\
39 \\
40 \\
41 \\
42 \\
43 \\
44 \\
47 \\
48 \\
51\end{array}$ & $\begin{array}{r}11 \\
14 \\
14 \\
14 \\
9 \\
10 \\
15 \\
11 \\
14 \\
10 \\
16 \\
15 \\
7 \\
12 \\
13 \\
12 \\
7 \\
13 \\
14 \\
10 \\
9 \\
8 \\
9 \\
8 \\
10 \\
14 \\
8 \\
13 \\
9 \\
7 \\
13 \\
6 \\
13 \\
10 \\
12 \\
9 \\
12 \\
6 \\
11 \\
14 \\
5 \\
8 \\
12 \\
8\end{array}$ & 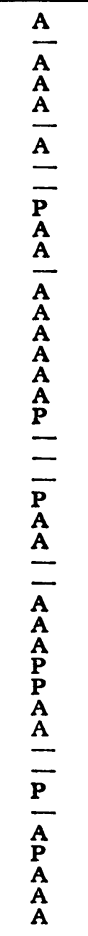 & $\begin{array}{l}\mathbf{A} \\
\mathbf{A} \\
\mathbf{A} \\
\mathbf{A} \\
\mathbf{A} \\
\mathbf{A} \\
\mathbf{P} \\
\mathbf{A} \\
\mathbf{P} \\
\mathbf{A} \\
\mathbf{A} \\
\mathbf{A} \\
\mathbf{A} \\
\mathbf{A} \\
\mathbf{A} \\
\mathbf{P} \\
\mathbf{A} \\
\\
\mathbf{Z} \\
\mathbf{A} \\
\mathbf{P} \\
\mathbf{A} \\
\mathbf{A} \\
\mathbf{A} \\
\mathbf{A} \\
\mathbf{P} \\
\mathbf{A} \\
\mathbf{A} \\
\mathbf{A} \\
\mathbf{P} \\
\mathbf{P} \\
\mathbf{A} \\
\mathbf{A} \\
\mathbf{A}\end{array}$ & $\begin{array}{r}0 \\
1 \\
5 \\
0 \\
0 \\
7 \\
5 \\
2 \\
4 \\
9 \\
0 \\
0 \\
9 \\
3 \\
7 \\
6 \\
0 \\
0 \\
0 \\
6 \\
0 \\
1 \\
0 \\
0 \\
26 \\
21 \\
1 \\
0 \\
0 \\
2 \\
0 \\
49 \\
2 \\
0 \\
9 \\
2 \\
2 \\
0 \\
0 \\
1 \\
0 \\
0 \\
11 \\
8\end{array}$ & $\begin{array}{r}10 \\
0 \\
17 \\
1 \\
3 \\
3 \\
16 \\
5 \\
3 \\
1 \\
17 \\
0 \\
4 \\
11 \\
17 \\
14 \\
12 \\
0 \\
2 \\
4 \\
0 \\
6 \\
0 \\
0 \\
33 \\
23 \\
3 \\
0 \\
0 \\
2 \\
16 \\
35 \\
5 \\
19 \\
24 \\
8 \\
2 \\
0 \\
14 \\
9 \\
0 \\
2 \\
12 \\
33\end{array}$ & $\begin{array}{r}70 \\
55 \\
31 \\
55 \\
80 \\
59 \\
61 \\
87 \\
68 \\
65 \\
65 \\
75 \\
100 \\
51 \\
54 \\
66 \\
72 \\
73 \\
62 \\
37 \\
74 \\
74 \\
55 \\
77 \\
59 \\
24 \\
79 \\
47 \\
75 \\
84 \\
62 \\
42 \\
59 \\
50 \\
49 \\
27 \\
55 \\
43 \\
75 \\
73 \\
70 \\
71 \\
60 \\
40\end{array}$ & $\begin{array}{r}51 \\
43 \\
37 \\
48 \\
85 \\
57 \\
39 \\
89 \\
53 \\
45 \\
45 \\
39 \\
135 \\
49 \\
44 \\
45 \\
34 \\
73 \\
62 \\
28 \\
73 \\
66 \\
52 \\
87 \\
41 \\
26 \\
69 \\
30 \\
68 \\
61 \\
29 \\
77 \\
64 \\
39 \\
23 \\
43 \\
54\end{array}$ & $\begin{array}{r}93 \\
70 \\
68 \\
68 \\
85 \\
74 \\
74 \\
94 \\
85 \\
88 \\
84 \\
82 \\
110 \\
74 \\
77 \\
85 \\
75 \\
96 \\
85 \\
65 \\
84 \\
91 \\
80 \\
94 \\
80 \\
47 \\
92 \\
75 \\
98 \\
112 \\
78 \\
51 \\
90 \\
89 \\
70 \\
54 \\
84 \\
66 \\
103 \\
89 \\
80 \\
98 \\
69 \\
65\end{array}$ & 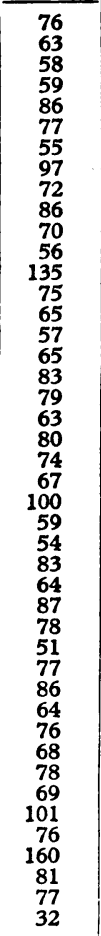 & $\begin{array}{r}+37 \\
+27 \\
-18 \\
+13 \\
-5 \\
+29 \\
+54 \\
-2 \\
+29 \\
+46 \\
+45 \\
+90 \\
-26 \\
+5 \\
+22 \\
+45 \\
+110 \\
0 \\
0 \\
+32 \\
+2 \\
+7 \\
+6 \\
-12 \\
+45 \\
-7 \\
+13 \\
+59 \\
+10 \\
+38 \\
+110 \\
-44 \\
-7 \\
+27 \\
+114 \\
-32 \\
+1 \\
-9 \\
-14 \\
+19 \\
+56 \\
+12 \\
-15 \\
+130\end{array}$ & $\begin{array}{r}+24 \\
+13 \\
+17 \\
+16 \\
-10 \\
-4 \\
+36 \\
-3 \\
+19 \\
+2 \\
+21 \\
+47 \\
-18 \\
-9 \\
+18 \\
+49 \\
+16 \\
+17 \\
+18 \\
+3 \\
+5 \\
+23 \\
+19 \\
-6 \\
+34 \\
-12 \\
+10 \\
+17 \\
+56 \\
+43 \\
+56 \\
+33 \\
+4 \\
+39 \\
-9 \\
-25 \\
+8 \\
+5 \\
-1 \\
+17 \\
+50 \\
+14 \\
-11 \\
+100\end{array}$ & $\begin{array}{c}5 \\
5 \\
5 \\
\text { Nil } \\
5 \\
\text { Nil } \\
5 \\
\text { Nil } \\
\text { Nil } \\
\text { Nil } \\
7 \cdot 5 \\
\text { Nil } \\
\text { Nil } \\
5 \\
10 \\
5 \\
\text { Nil } \\
5 \\
5 \\
7 \cdot 5 \\
\mathrm{Nil} \\
\mathrm{Nil} \\
\mathrm{Nil} \\
\mathrm{Nil} \\
5 \\
15 \\
5 \\
10 \\
\mathrm{Nil} \\
\mathrm{Nil} \\
\mathrm{Nil} \\
5 \\
\mathrm{Nil} \\
2.5 \\
\mathrm{Nil} \\
\mathrm{Nil} \\
\mathrm{Nil} \\
\mathrm{Nil} \\
\mathrm{Nil} \\
\mathrm{Nil} \\
\mathrm{Nil} \\
\mathrm{Nil} \\
\mathrm{Nil} \\
\mathrm{Nil}\end{array}$ & $\begin{array}{l}5 \\
5 \\
5 \\
\text { Nil } \\
5 \\
\text { Nil } \\
5 \\
\text { Nil } \\
\text { Nil } \\
\text { Nil } \\
2 \cdot 5 \\
\text { Nil } \\
\text { Nil } \\
2 \cdot 5 \\
5 \\
\text { Nil } \\
\text { Nil } \\
5 \\
5 \\
7 \cdot 5 \\
\text { Nil } \\
\text { Nil } \\
\text { Nil } \\
\text { Nil } \\
5 \\
15 \\
5 \\
\text { Nil } \\
\text { Nil } \\
5 \\
\text { Nil } \\
5 \\
\text { Nil } \\
\text { Nil } \\
\text { Nil } \\
\text { Nil } \\
\text { Nil } \\
\text { Nil } \\
\text { Nil } \\
\text { Nil } \\
\text { Nil } \\
5 \\
\text { Nil } \\
\text { Nil }\end{array}$ & $\begin{array}{c}2 \cdot 5 \\
5 \\
5 \\
\mathbf{N i l} \\
5 \\
\mathrm{Nil} \\
5 \\
\mathbf{N i l} \\
\mathbf{N i l} \\
\mathrm{Nil} \\
2 \cdot 5 \\
\mathbf{N i l} \\
\mathrm{Nil} \\
2 \cdot 5 \\
5 \\
\mathbf{N i l} \\
\mathrm{Nil} \\
2 \cdot 5 \\
2 \cdot 5 \\
7 \cdot 5 \\
\mathbf{N i l} \\
\mathrm{Nil} \\
\mathrm{Nil} \\
\mathrm{Nil} \\
5 \\
10 \\
5 \\
\mathrm{Nil} \\
\mathrm{Nil} \\
\mathrm{Nil} \\
\mathrm{Nil} \\
5 \\
\mathrm{Nil} \\
\mathrm{Nil} \\
\mathrm{Nil} \\
\mathrm{Nil} \\
\mathrm{Nil} \\
\mathrm{Nil} \\
\mathrm{Nil} \\
\mathrm{Nil} \\
\mathrm{Nil} \\
\mathrm{Nil} \\
\mathrm{Nil} \\
\mathrm{Nil}\end{array}$ & $\begin{array}{c}\text { Nil } \\
2 \cdot 5 \\
5 \\
\text { Nil } \\
5 \\
\text { Nil } \\
5 \\
\text { Nil } \\
\text { Nil } \\
\text { Nil } \\
2 \cdot 5 \\
\text { Nil } \\
\text { Nil } \\
2 \cdot 5 \\
2 \cdot 5 \\
\text { Nil } \\
\text { Nil } \\
\text { Nil } \\
2 \cdot 5 \\
2 \cdot 5 \\
\text { Nil } \\
\text { Nil } \\
\text { Nil } \\
\text { Nil } \\
5 \\
\text { Nil } \\
5 \\
\text { Nil } \\
\text { Nil } \\
\text { Nil } \\
\text { Nil } \\
? \\
\text { Nil } \\
\text { Nil } \\
\text { Nil } \\
\text { Nil } \\
\text { Nil } \\
5 \\
\text { Nil } \\
\text { Nil } \\
\text { Nil } \\
\text { Nil } \\
\text { Nil } \\
?\end{array}$ & $\begin{array}{c}\text { Nil } \\
2 \\
30 \\
5 \\
\text { Nil } \\
\text { Nil } \\
65 \\
\text { Nil } \\
\text { Nil } \\
12 \\
\text { Nil } \\
\text { Nil } \\
\text { Nil } \\
4 \\
\text { Nil } \\
12 \\
\text { Nil } \\
\text { Nil } \\
\text { Nil } \\
\text { Nil } \\
\text { Nil } \\
22 \\
\text { Nil } \\
11 \\
8 \\
97 \\
\text { Nil } \\
\text { Nil } \\
\text { Nil } \\
\text { Nil } \\
\text { Nil } \\
\text { Nil } \\
\text { Nil } \\
11 \\
14 \\
6 \\
\text { Nil } \\
\text { Nil } \\
\text { Nil } \\
17 \\
\text { Nil } \\
\text { Nil } \\
11 \\
\text { Nil }\end{array}$ & $\begin{array}{cl}15 \\
\text { Nil } \\
122 \\
\text { Nil } \\
2 \\
\text { Nil } \\
84 \\
\text { Nil } \\
\text { Nil } \\
\text { Nil } \\
69 \\
\text { Nil } \\
\mathrm{Nil} \\
24 \\
17 \\
28 \\
19 \\
\text { Nil } \\
\mathrm{Nil} \\
\mathrm{Nil} \\
\mathrm{Nil} \\
20 \\
\mathrm{Nil} \\
12 \\
23 \\
113 \\
\mathrm{Nil} \\
\mathrm{Nil} \\
\mathrm{Nil} \\
\mathrm{Nil} \\
13 \\
\mathrm{Nil} \\
\mathrm{Nil} \\
17 \\
6 \\
15 \\
\mathrm{Nil} \\
\mathrm{Nil} \\
\mathrm{Nil} \\
23 \\
\mathrm{Nil} \\
\mathrm{Nil} \\
3 \\
53\end{array}$ \\
\hline
\end{tabular}

- Assessor's independent preference was based on the scrutiny of all records.

4 Patient's preference was based on the overall assessment of symptoms at the end of each period of treatment.

\$ The asthma disability score was derived from the record cards during the final two weeks of each period. For each day and each night the patient recorded numerically the degree of disability as indicated in Fig. 1. The maximum score for each day or night indicating no disability would be 84 . The actual score was subtracted from 84 for both day and night and the mean of these figures taken as the asthma disability score.

$\$$ Predicted normal values were based on height (Strang, 1959).

$\| \%$ change $=\frac{\text { Active }- \text { Placebo }}{\text { Placebo }} \times 100$.

I The total number of times the inhaler was used during the final two weeks in each period of treatment as recorded in the daily records. 
the placebo or active periods. The remaining case was withdrawn from the sequential trial because his code was broken during the first four-week period, when it was noted that he had raised serum transaminase levels though he did not develop any clinical illness. In fact he had not yet received disodium cromoglycate, and in view of the rapid return to normality in the transaminase levels he completed the trial and his results have been included in the further analysis (Case 11).

\section{Further Analysis}

Of the 51 cases originally admitted to the trial three were withdrawn within the first month because of failure to cooperate in taking the treatment regularly; the records of three further patients were incomplete. One other boy developed infective hepatitis before he had received disodium cromoglycate, and it was decided to withdraw him altogether. Thus 44 patients completed the trial satisfactorily, and the principal results from these children are given in Table $I$. The values shown in Table I were all obtained during the last two weeks of each treatment period in order that a change in the pattern of the patient's condition resulting from treatment could become established, as well as to reduce the possibility that a "carry-over" effect might have influenced the results. Statistical analyses of these results was carried out in a number of different ways.

Preference Data.-The assessor was able to state a preference for "active" or "placebo" in 31 cases. He chose active on 24 occasions and placebo on seven ( $\chi^{2}$ with Yates's correction $=8.26, \mathrm{P}<0.005)$. Thirty-two patients stated their own preference-25 for "active" and 7 for "placebo" ( $\chi^{2}$ with Yates's correction $=9.04, \mathrm{P}<0.005)$. Thus the preference of both assessor and patients for the "active" period are statistically highly significant. The order in which the drugs were administered and the concurrent administration of steroids did not significantly affect the patients' or assessor's preference $(\mathrm{P}>$ 0.05).

$t$-Test for Paired Data.-There was no statistically significant difference in the F.E.V., values of the group as a whole, whereas the F.V.C. values were significantly higher during the "active" period in these patients. There were significant differences in the spirometric results in favour of the drug in the patients whose F.E.V..$_{1}$ or F.V.C. values were less than

\begin{tabular}{|c|c|c|c|c|c|}
\hline \multirow{2}{*}{ Group } & \multirow{2}{*}{$\begin{array}{c}\text { No. } \\
\text { of } \\
\text { Patients }\end{array}$} & \multirow{2}{*}{$\begin{array}{c}\text { Index } \\
\text { of } \\
\text { Assessment }\end{array}$} & \multicolumn{2}{|c|}{ Treatment Period } & \multirow{2}{*}{$\begin{array}{l}\text { Proba- } \\
\text { bility } \ddagger\end{array}$} \\
\hline & & & Placebo & Active & \\
\hline \multirow{3}{*}{ All patients } & 44 & F.V.C. values* & $75 \cdot 4^{*}$ & $81 \cdot 2 t$ & \\
\hline & 44 & $\begin{array}{l}\text { (\% predicted) } \\
\text { F.E.V.1 values }\end{array}$ & $\pm 21 \cdot 0$ & $\pm \underset{61 \cdot 6 t}{14 \cdot 2}$ & $<0.05$ \\
\hline & & (\% predicted) & $\pm 24 \cdot 7$ & \pm 16.2 & N.S. \\
\hline $\begin{array}{l}\text { F.V.C. } \leqslant 80 \% \text { of } \\
\text { predicted value } \\
\text { during placebo } \\
\text { period }\end{array}$ & 32 & $\begin{array}{l}\text { F.V.C. values* } \\
\text { (\% predicted) }\end{array}$ & $\begin{aligned} & 66 \cdot 7 \dagger \\
\pm & 10 \cdot 7\end{aligned}$ & $\begin{aligned} & 76 \cdot 3 \dagger \\
\pm & 13 \cdot 0\end{aligned}$ & $<0.001$ \\
\hline $\begin{array}{l}\text { F.V.C. } \leqslant 80 \% \text { of } \\
\text { predicted value } \\
\text { during either } \\
\text { period }\end{array}$ & 33 & $\begin{array}{l}\text { F.V.C. values* } \\
\text { (\% predicted) }\end{array}$ & $\begin{array}{r}69.5 \dagger \\
\pm 19.3\end{array}$ & $\begin{aligned} & 76.5 \dagger \\
& \pm 12.8\end{aligned}$ & N.S. \\
\hline $\begin{array}{l}\text { F.E.V.1 } \leqslant 80 \% \text { of } \\
\text { predicted value } \\
\text { during placebo } \\
\text { period }\end{array}$ & 38 & $\begin{array}{l}\text { F.E.V.1 values* } \\
\text { (\% predicted) }\end{array}$ & $\begin{aligned} & 49 \cdot 2 \dagger \\
\pm & 15 \cdot 4\end{aligned}$ & $\begin{aligned} & 58.4 \dagger \\
\pm & 14.6\end{aligned}$ & $<0.001$ \\
\hline $\begin{array}{l}\text { F.E.V.1 } 1 \leqslant 80 \% \text { of } \\
\text { predicted value } \\
\text { during either } \\
\text { period }\end{array}$ & 42 & $\begin{array}{l}\text { F.E.V.1 values* } \\
\text { (\% predicted) }\end{array}$ & $\begin{aligned} & 53.8 \dagger \\
\pm & 21.3\end{aligned}$ & $\begin{aligned} & 60 \cdot 1 \dagger \\
\pm & 14.8\end{aligned}$ & $<0.05$ \\
\hline $\begin{array}{l}\text { Patients record- } \\
\text { ing asthma dis- } \\
\text { ability }\end{array}$ & 35 & $\begin{array}{l}\text { Asthma dis- } \\
\text { ability score* }\end{array}$ & $\begin{array}{r}11.0 \dagger \\
\pm 9.7\end{array}$ & $\begin{array}{r}5 \cdot 7 t \\
\pm 9 \cdot 5\end{array}$ & $<0.001$ \\
\hline \multirow[t]{2}{*}{$\begin{array}{l}\text { Patients using in- } \\
\text { haler }\end{array}$} & 23 & $\begin{array}{l}\text { Inhaler usage* } \\
\text { (No. of times } \\
\text { used) }\end{array}$ & $\begin{array}{r}29.5 t \\
\pm 34.9\end{array}$ & $\begin{array}{l}12.5 \dagger \\
\pm 23.4\end{array}$ & $<0.005$ \\
\hline & 44 & $\begin{array}{l}\text { Significant im- } \\
\text { provement } \\
\text { (independent } \\
\text { assessor's } \\
\text { opinion) }\end{array}$ & 7 & 24 & $<0.005$ \\
\hline All patients & 44 & $\begin{array}{l}\text { Patient's prefer- } \\
\text { ence }\end{array}$ & 7 & 25 & $<0.005$ \\
\hline
\end{tabular}

* Values relate to last two weeks of each period.

+ Values are mean \pm S.D.

$\ddagger$ Based on $t$-test for paired data or $\chi^{2}$ test.
N.S. $=\mathrm{P}>0.0 .5$.
$80 \%$ of their predicted normal during the placebo period as well as in those whose F.E.V. ${ }_{1}$ was less than $80 \%$ of their predicted normal during either period. There was also a significant difference in the asthma score in favour of "active" treatment in those patients recording asthma disability as well as in the use of inhalers. These results are summarized in Table II.

In Fig. 3 the correlation between the opinion of the independent assessor and that of the patient, and the percentage change in F.E.V..$_{1}$ are shown graphically. The patient's opinion of his overall chest symptoms was obtained from the questionary completed at the end of the "active" period and recorded on a five-point scale as follows: -2 much worse, -1 slightly worse, 0 about the same, +1 slightly better, +2 much better. A similar method of scoring was used for the placebo period but the signs were reversed. The horizontal co-ordinate of each case was determined by the sum of the two scores. Points to the right of the origin are in favour of the drug, and vice versa. The results show a considerable degree of agreement between the opinions of the assessor, the patient, and the ventilatory tests, though it is apparent that in individual cases an improvement in F.E.V. values did not always correlate with the opinion of the patient or of the assessor, and vice versa. Similarly, the opinions of the assessor and of the patient were not always in agreement.
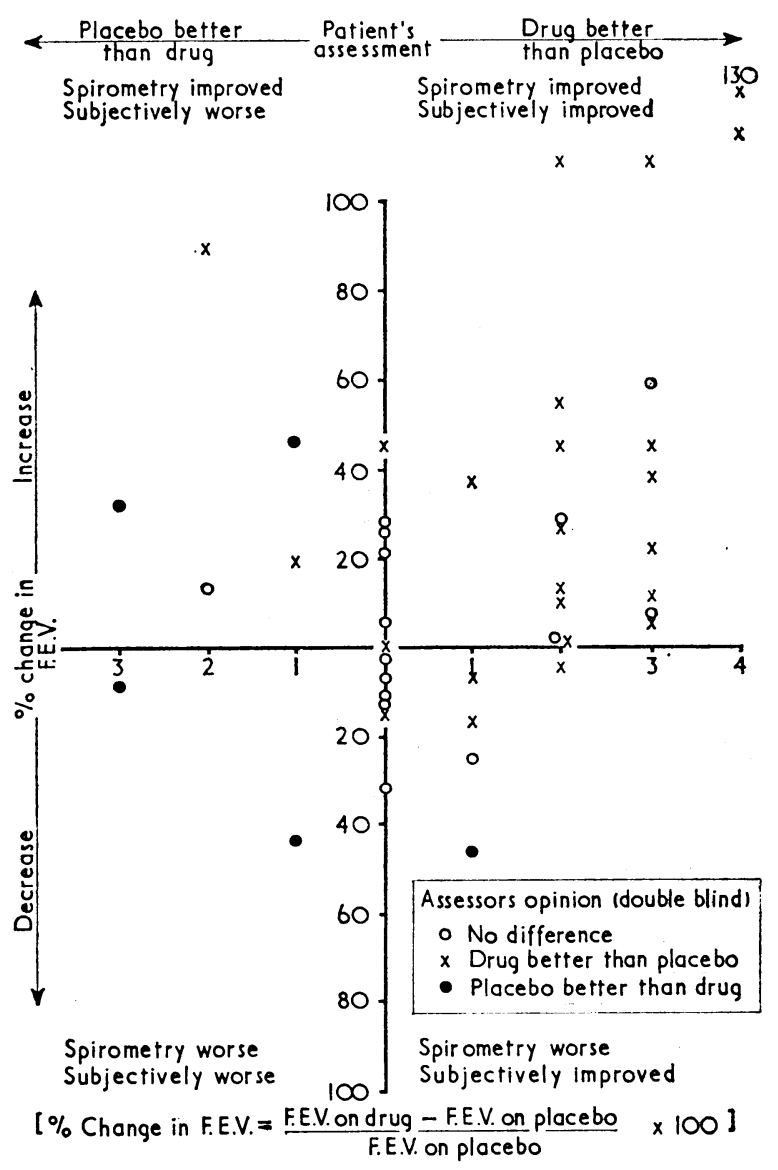

FIG. 3.- Correlation between opinion of independent assessor and that of patient, and the percentage change in F.E.V...

\section{Corticosteroid Dosage}

From Table I it will be seen that two patients (Cases 47 and 34) required steroid treatment only during the placebo period, though they had not been on steroid treatment before the trial. In both cases disodium cromoglycate was given during the first period and a clinical deterioration occurred when placebo was substituted. Three patients (Cases 17, 30, and 38) who had been on steroids before the trial discontinued this treatment when disodium cromoglycate was introduced, but they did not 
relapse sufficiently during the subsequent placebo period to require reintroduction of steroids. All three cases remained off steroid treatment during the three months of known treatment with disodium cromoglycate after the trial (see below).

Four patients (Cases 1, 19, 20, and 28) who were given placebo during the first period were maintained on a reduced steroid dose when they changed to disodium cromoglycate in the second period. Three patients (Cases 12, 15, and 16) who had reduced the dose of steroids during the initial four weeks while receiving disodium cromoglycate were maintained on a reduced dosage during the subsequent placebo period. In two of these the lower steroid dose was maintained for three months while receiving disodium cromoglycate, and in one case the steroid dose was reduced even further.

The steroid dosages in 18 cases at the end of the three months of known disodium cromoglycate therapy compared with those at the start of the trial show the following: steroids discontinued in five (Cases 1, 17, 28, 30, and 38), reduced in six (Cases 2, $12,15,16,20$, and 21), unchanged in six. In one patient (Case 42) who had not responded to disodium cromoglycate over a two-month period a small dose of prednisolone was substituted instead.

\section{Bronchodilator Usage}

Twenty-three out of the 44 patients recorded in Table I used aerosol bronchodilators during the period of the trial. According to their records this was discontinued during the "active" treatment period in six cases, used less in 13 cases, and used more often in four cases. The number of doses inhaled was reduced from an average of 30 a patient during the placebo period to 13 during the active period (Table II).

\section{Further Studies}

Of the 44 patients who completed the trial 42 were treated for a further three months with disodium cromoglycate on an open basis. Of these, 22 had shown, in the opinion of the independent assessor, initial improvement during the month of "active" treatment, and this was maintained on long-term treatment in $20(91 \%)$ but not maintained in $2(9 \%)$. There were 20 patients who had not shown improvement in the month on active treatment but on long-term treatment $6(30 \%)$ did show improvement, though $14(70 \%)$ did not.

While the trial period of one month did seem to give quite a good indication of the patients who might be improved on disodium cromoglycate it seems likely that a longer period of two or even three months would have given a better indication of which patients would benefit, and the effect may in some cases be manifest slowly. Two of the patients who failed to improve on long-term treatment developed soreness of the throat and stopped the treatment before completing the full three months.

\section{Side-effects}

Blood specimens were taken initially and at monthly intervals during the trial for haemoglobin, E.S.R., R.B.C., W.B.C., and differential white cell counts. Alkaline phosphatase, serum alanine aminotransferase, and serum aspartate aminotransferase were also measured. Urine specimens were examined weekly for sugar and protein. No abnormalities which could be ascribed to disodium cromoglycate occurred. One patient suffered from hoarseness and dryness of the mouth during the trial, which was quickly relieved when inhalation of the powder was stopped. This effect seemed to occur with both the active and the placebo powder. Two other patients complained of a similar effect during the three months of known treatment after the trial, recovering when it was stopped.

\section{Conclusion}

Our results with disodium cromoglycate in the treatment of children with asthma agree more with those of Howell and Altounyan (1967) and of Kennedy (1967) than with the less encouraging report of Grant et al. (1967). The severity of asthma during the double-blind trial was assessed by several methods in which both objective and subjective criteria were used: all these methods suggested improvement on the drug. Some cases showed no detectable improvement on the drug; some of these non-responders were in a phase of remission so that their disability was minimal at the time of the trial. The opinion of the independent assessor was that in $24(54 \%)$ of the 44 patients who completed the trial the patient was improved while on treatment. Twenty-five $(57 \%)$ of them felt better on treatment. In $29(66 \%)$ the F.E.V. 1 was improved and in 30 $(68 \%)$ the F.V.C. was improved compared with the readings in the placebo period.

Overall improvement seemed to be maintained in 20 out of 22 patients $(91 \%)$ over a further three-month period of open treatment. Out of 20 patients who had not shown improvement after one month of treatment $6(30 \%)$ did benefit after a further three months.

With its apparent freedom from serious side-effects, the reduction or successful replacement of steroid therapy in many cases may prove to be among the greatest benefits to be expected.

\section{Summary}

A double-blind crossover clinical trial of disodium cromoglycate (Intal) administration by inhalation for the treatment of asthma in 44 children has shown this preparation to have a beneficial effect. There were no ill effects except for occasional soreness of the throat and hoarseness. Some patients who had previously required continuous corticosteroid therapy were able to reduce the dose or to discontinue treatment without clinical deterioration. In most cases no loss of clinical benefit was observed over a three-month period of treatment. Much remains to be learned about the mode of action, the long-term effects, and the selection of suitable subjects for this novel method of treatment. Our results are encouraging and justify further study.

We would like to record our gratitude to Dr. L. A. McDowall, consultant chest physician and director of the Birmingham Mass Radiography Service, who carried out the independent assessments, and to Dr. V. H. Springett, consultant chest physician and medical director of the Birmingham Chest Service, who prepared the sequential chart. We are indebted to Dr. H. G. Sammons, consultant biochemist, and Dr. R. H. B. Protheroe, consultant pathologist at the East Birmingham Hospital, for the laboratory studies, and to the nursing staff of the asthma clinic of the Birmingham School Health Service. Finally, we should like to thank Dr. J. S. G. Cox, research director of Fisons Pharmaceuticals Limited, and his staff for the supply of materials and for their help in the tabulation of our results.

Requests for reprints should be addressed to Dr. J. Morrison Smith, Birmingham Chest Clinic, 151 Great Charles Street, Birmingham 3.

\section{REFERENCES}

Altounyan, R. E. C. (1968). Acta allerg. In press.

Altounyan, R. E. C., and Howell, J. B. L. (1968). Med. thorac. (Basel). In press.

Cox, J. S. G. (1967). Nature (Lond.), 216, 1328

Grant, I. W. B., Channell, S., and Drever, J. C. (1967). Lancet, 2, 673.

Howell, J. B. L., and Altounyan, R. E. C. (1967). Lancet, 2, 539.

Kennedy, M. C. S. (1967). Lancet, 2, 838.

Smith, J. M. (1965). Ann. Allergy, 23, 492.

Smith, J. M. (1965). Ann. Allergy, 23,
Strang, L. B. (1959). Thorax, 14, 305. 